https://doi.org/10.31516/2410-5325.062.18

УДК 008.001.361:37]:316.723.094.4(477.6)

О. О. Смоліна, доктор культурології, доцент, Східноукраїнський національний університет імені Володимира Даля, м. Сєвєродонецьк laprimavera555@gmail.com http://orcid.org/0000-0003-2369-3738

А. М. Ополонін, кандидат філософських наук, доцент, Східноукраїнський національний університет імені Володимира Даля, м. Сєвєродонецьк opolonin@ukr.net http://orcid.org/0000-0002-2486-1177

\title{
КУЛЬТУРНА ІДЕНТИЧНІСТЬ ЯК ДИНАМІЧНЕ УТВОРЕННЯ (НА ПРИКЛАДІ КУЛЬТУРНОЇ САМОІДЕНТИФІКАЦІЇ НАСЕЛЕННЯ СХІДНИХ ОБЛАСТЕЙ УКРАЇНИ)
}

Автори статті звертають увагу на актуальність культурологічного аналізу подій на Сході України, які значно впливають не лише на політичне, але й на культурне життя країни. Зокрема потребує вирішення питання формування політичної культури і національної культурної ідентичності жителів Сходу України. З 1991 р. їх орієнтації багато в чому визначалися як проросійські. Ґрунтуючись на сучасних соціологічних дослідженнях, автори констатують зміну культурної ідентичності жителів Сходу України з проросійської на проукраїнську. Це свідчить про динаміку культурної ідентичності як соціокультурного утворення і про відносини взаємного доповнення, у яких перебувають політична культура і культурна ідентичність.

Ключові слова: політична культура, культурна ідентичність, динаміка культурної ідентичності, нація, самоідентифікація.

О. О. Смолина, доктор культурологии, доцент, Восточноукраинский национальный университет имени Владимира Даля, г. Северодонецк

А. М. Ополонин, кандидат философских наук, доцент,

Восточноукраинский национальный университет имени Владимира Даля, г. Северодонецк

\section{КУЛЬТУРНАЯ ИДЕНТИЧНОСТЬ КАК ДИНАМИЧЕСКОЕ ОБРАЗОВАНИЕ (НА ПРИМЕРЕ КУЛЬТУРНОЙ САМОИДЕНТИФИКАЦИИ НАСЕЛЕНИЯ ВОСТОЧНЫХ ОБЛАСТЕЙ УКРАИНЫ)}

Авторы статьи обращают внимание на актуальность культурологического анализа событий на Востоке Украины, которые оказывают значительное влияние не только на политическую, но и на культурную жизнь страны. В частности остро стоит вопрос формирования политической культуры и национальной культурной идентичности жителей Востока Украины. С 1991 г. их ориентации во многом определялись как пророссийские. Основываясь на современных социологических исследованиях, авторы констатируют смену культурной идентичности жителей Востока Украины с пророссийской на проукраинскую. Это свидетельствует о динамике культурной идентичности как социокультурного образования и об отношениях взаимодополняемости политической культуры и культурной идентичности. 
Ключевые слова: политическая культура, культурная идентичность, динамика культурной идентичности, нация, самоидентификация.

0. O. Smolina, Doctor of Cultural Studies, Associate Professor, Volodymyr Dahl East Ukrainian National University, Severodonetsk

A. M. Opolonin, Candidate of Philosophy, Associate Professor, Volodymyr Dahl East Ukrainian National University, Severodonetsk

\section{CULTURAL IDENTITY AS A DYNAMIC PHENOMENON (CASE STUDY: CULTURAL SELF-IDENTIFICATION OF THE POPULATION OF THE EASTERN REGIONS OF UKRAINE)}

The aim of this paper is to specify the relationship of political culture and cultural identity, as well as to determine the presence of the dynamics of cultural identity and the nature of its changes in the self-identification of the residents of the eastern regions of Ukraine.

Research methodology. The article provides an analysis of the data of modern sociological research of the leading sociological centers of Ukraine, their interpretation from the point of view of the culturological approach.

Results. It has been found that the mutually intersecting sides of political culture and cultural identity are the sphere of emotions and value judgments, worldview, faith. From the point of view of cultural identity it is a part of the political culture, since for the formation of the reflection in relation to certain political institutions, it is necessary to identify oneself with the cultural tradition for which these institutions are related or, on the contrary, are alien. From the point of view of the cultural approach, the political culture is a part of cultural identity, as it acts as one of the parties or a component of self-identification with an individual with a particular cultural tradition and a multitude of its manifestations. The analysis of the sociological surveys shows that the cultural self-identification of the residents of the Ukrainian part of Luhansk region has undergone significant changes since 2014: the identification with Russian culture has been replaced by pro-Ukrainian orientation. Firstly, this characterizes the phenomenon of cultural identity as a dynamic one, and secondly, it enables to conclude that the systematic education of the population for the political culture, combined with the work on the cultural, educational and leisure activities, allows influencing the cultural self-identification of people, up to and including its cardinal change.

Novelty. The paper presents an attempt to analyze the features of the correlation of political culture and cultural identity from the point of view of the cultural approach. The authors substantiate the view of the change of the cultural selfidentification of the inhabitants of the East of Ukraine from the pro-Russian to the pro-Ukrainian identity by studying the newest sociological surveys.

The practical significance. The results will be used to continue the study of the ethno-cultural identity of the inhabitants of Ukraine.

Key words: political culture, cultural identity, dynamics of cultural identity, nation, self-identification.

Постановка проблеми. Трагічні події на Сході України, що розпочалися у 2014 р. і тривають понині, впливають не тільки на політичне, але, без сумніву, і на культурне життя нашої країни. І якщо політичних 
оцінкок (найширшого спектра) цих подій на сьогодні достатньо, то оцінки з позицій культури і культурології не настільки численні. Серед останніх переважають документи симпозіумів, круглих столів, засідань спецкомісій з проблеми збереження пам'яток історії та культури в зоні бойових дій (Бусол, Коваль, 2014; Російсько-украӥнська війна в кульmypi; Титова, 2016), приклади осмислення подій за допомогою засобів кінематографа (Верба, Алманд), заходи, присвячені пам'яті загиблих і особистостям українських воїнів. Власне ж культурологічне осмислення проблеми тільки розпочинається. Мабуть, дається взнаки особистісний аспект і гострота переживань цих подій, їх інтенсивна психологічна забарвленість і недостатня часова дистанція. Водночас минулі чотири роки дозволяють сформулювати деякі висновки, зокрема й у культурологічному контексті.

Актуальність культурологічного аналізу окремих аспектів сучасної ситуації на Сході України пов’язана з безперервними пошуками вирішення проблеми, яка є нагальною. А теорія і практика, як відомо, тісно взаємопов'язані. Зокрема важливим є питання політичної культури й культурної ідентичності населення прилеглих до зони конфлікту областей. У зв’язку із цим, мета статті - визначити наявність та проаналізувати динаміку культурної ідентичності населення деяких міст Луганської області, що розташовані поблизу зони бойових дій.

Відомо, що політична культура і культурна ідентичність мають кілька секторів, які взаємно перетинаються. Політична культура - це не тільки участь у політичному житті, політична поведінка, а й історичний досвід, пам'ять, світогляд. Це оцінка людьми політичних подій, політичних рішень. Сутністю політичної культури є сукупність політичних знань, індивідуальних позицій, орієнтацій, дій суб'єктів політичного життя суспільства. Нинішня політична культура - це підсумок політичної освіти, важлива складова духовного життя суспільства, яка набуває вираження в політичній поведінці. Г. Алманд і С. Верба стверджували (Верба, Алманд), що політична культура - це політична система, відбита у свідомості, почуттях і оцінках населення.

Тобто політична культура містить немало суб'єктивних, психологічних, оціночних складових. 3 точки зору психології в політичній культурі виокремлюють такі ознаки:

1) знання і віра: ідеться про ставлення кожного індивіда до своєї нації, політичної системи, знання історії нації, силу їі впливу у світі ТОщо;

2) почуття й емоції: що відчуває і знає індивід про структуру і роль політичних еліт, їх політичні ініціативи, практику політичного примусу, свій доступ до політичної системи і вплив на неї; 
3) судження й думки: як індивід ставиться до політичної системи, у якій існує, яку думку має щодо іiї переваг і недоліків, її зміну або незмінність.

Отже, політична культура втілюється в переконаннях, ідеалах, принципах, поглядах, поведінці.

Явища політичного життя загалом і політичної культури зокрема тісно пов’язані з проблемою культурної ідентичності, оскільки в сучасних умовах самоусвідомлення і самовизначення людини, нації, держави неможливі без здійснення певного політичного вибору. Уперше в науці термін «ідентичність» долучив до наукового обігу американський психолог Ерік Еріксон (Эриксон). Він стверджував, що ідентичність є «фундаментом» будь-якої особистості і показником її психосоціального благополуччя, містить такі моменти:

- внутрішню тотожність суб'єкта в процесі сприйняття навколишнього світу, відчуття часу й простору, іншими словами, це відчуття й усвідомлення себе як унікальної автономної індивідуальності;

- тотожність особистих і соціально прийнятих світоглядних настанов - особистісна ідентичність і душевне благополуччя;

- почуття долученості Я людини до певної спільноти.

Тільки перебуваючи серед інших людей (зокрема взаємодіючи 3 ними з питань політичного життя) людина набуває ідентичності, яка необхідна для впорядкування свого життя. Вона добровільно приймає пануючі в цьому співтоваристві смаки, звички, норми, цінності, соціокультурні практики маніфестації єдності, принципи взаємодії та інші засоби взаємозв'язку, створені членами певної спільноти. Засвоєння цих елементів робить її причетною до відповідної культурної традиції. Кожен індивід є водночас членом декількох різних соціокультурних груп, тому йому притаманні кілька ідентичностей.

Культурна ідентичність полягає в прийнятті людиною зразків поведінки, характерних для певної культури, розумінні належності до цієї культури і носія iï архетипів, ціннісних настанов. Культурна ідентичність має важливе значення в житті індивіда, оскільки формує ставлення до самого себе, інших людей, суспільства і світу.

Культурна ідентичність не характеризується як надзвичайно динамічне утворення, тому що формується повільно і пов'язана з душевними переживаннями, особистою гідністю, пошуками індивідуальності. Водночас людина може втратити ідентичність, відчуваючи чужість навколишнього світу стосовно себе. Це може бути пов'язано з віковими кризами, маргіналізацією індивіда, змінами соціокультурного середовища, коли людина просто не може з потрібною швидкістю адаптуватися до нових умов життя. 
Отже, аспекти політичної культури і культурної ідентичності, що взаємно перетинаються, - це сфера емоцій і оціночних суджень, світогляд, віра. В «укрупненому» вигляді це три базові компоненти - рефлексивний, емоційний і поведінковий (на основі перших двох). Крім того, з точки зору діяльнісного підходу, культурна ідентичність є складовою політичної культури, тому що для формування рефлексії стосовно певних політичних інститутів необхідне попереднє ототожнення себе 3 культурною традицією, для якої ці інститути будуть спорідненими або, навпаки, чужими. 3 точки зору власне культурологічного підходу, політична культура - складова культурної ідентичності, один із компонентів ідентифікації себе індивідом відповідно до тієї чи іншої культурної традиції в безлічі її проявів.

Загальновідомо, що культурна самоідентифікація населення сучасної України не характеризується однорідністю і безпроблемністю. У 2016 р. український центр імені Разумкова провів масштабне соціологічне опитування (Социологический опрос, проведенный иентром Разумкова 18-23 ноября 2016 г.) щодо основних проблем формування сучасної ідентичності української нації. Основним висновком цього дослідження стало те, що ключовою проблемою в цьому питанні є брак довіри у відносинах між громадянами України. Ідентичність, сформована в Західній Україні (з ядром в Галичині), практично співпадає з ідентичністю громадян Центральної України, у цих областях основні культурноціннісні характеристики є практично однаковими. Складніша ситуація на Півдні та Сході, особливо на Донбасі, де характеристики значно різняться. Тут існують три серйозні проблеми.

Перша - відсутність згоди щодо того, якою повинна бути в майбутньому українська нація: сформуватися як щось єдине, де всі етнічні групи вливаються і асимілюються українським етносом, або слід зберігати єдність в розмаїтті різних етнічних груп. Громадяни поділилися в цьому питанні практично навпіл: 41\% вважають, що в Україні потрібно розвивати і зберігати різні культурні традиції, а 36\% переконані, що слід зближувати їх з культурою українського етносу.

Другою проблемою є те, що близько 30\% громадян у південносхідних регіонах і на Донбасі вважають україномовних та російськомовних українців двома різними народами.

Третя велика проблема - це уявлення про українців і росіян як про два братні народи. У 2013 р. так вважали 61\%, а у 2016 - 51\% (!). 92\% жителів України вважають себе українцями за національністю. Щоправда, тільки 70\% з них сприймають українську мову як рідну й лише 55\% говорять нею вдома.

У регіональному розрізі мовна картина ще різноманітніша. Наприклад, на Донбасі українську мову рідною вважають приблизно 
$28 \%$ населення, а говорять лише 7,6\%. Водночас російська рідна для $66 \%$, а розмовляють нею 90,5\%. Парадоксальність ситуації полягає в тому, що в цьому регіоні українцями за національністю називають себе $60 \%$ населення.

Для громадян Харківської, Дніпропетровської, Запорізької областей українська мова є рідною для $43 \%$, розмовляють нею вдома $29 \%$. Російська рідна для $52 \%$, а розмовляють $67 \%$.

Краща ситуація на Півдні України - Херсон, Миколаїв, Одеса: українська є рідною для 63\%, а говорять переважно нею 33,5\%. Відповідно, російська є рідною для 31\%, але використовують ï в побуті 60,5\%. Водночас $42 \%$ жителів Півдня вважають, що українську мову слід знати, а вдома спілкуватися мовою, хто якою хоче.

Наведені дані щодо Донбасу проявились раніше, в подіях, що відбувалися в Луганській і Донецькій областях у 2014-2015 рр. У зв’язку з бойовими діями в квітні-липні 2014 р. на Донбасі 1,5 млн людей були змушені покинути рідні місця. Люди їхали в Західну, Центральну Україну, але досить значна кількість - в Росію. Кожен обирав нове місце проживання відповідно до своїх переконань, ідентичності.

Загалом населення Південно-Східної України тяжіло до Російської Федерації, російської історичної і культурної традиції. Це можна пояснити близькістю культур, спільністю російської мови, релігії, тобто того, що ми вкладаємо в поняття «політична культура» і «культурна ідентичність». Слід зазначити, що після розпаду Радянського Союзу в 1991 р. відносини Росії і України складаються непросто. Україна зі здобуттям незалежності різко змінила свій зовнішньополітичний вектор до Євросоюзу і НАТО, США. Для багатьох громадян Південно-Східної України стало неприємною несподіванкою дізнатися те, що вони є «національною меншиною». Численні історичні образи і взаємні претензії перешкоджають взаєморозумінню в національній, культурній, політичній та економічній сферах.

Підтвердженням може слугувати сумнозвісний референдум про збереження статусу областей або надання їм статусу автономії, проведений на окупованій території Донбасу 11 травня 2014 року. Зокрема в м. Сєвєродонецьк явка склала 78\%, а 97\% з тих жителів, хто проголосував, віддали свій голос за автономію Луганської області, підтведивши своє прагнення до «русского мира». 22 липня 2014 р. Збройні Сили України звільнили м. Сєвєродонецьк від бойовиків, яких підтримувала Росія.

Цікаво простежити, чи змінились за минулі чотири роки свідомість людей, їх світогляд, менталітет, політична культура та ідентичність. Державна влада України за цей час виконала величезну роботу сто- 
совно зближення культур і ціннісних орієнтацій населення Західної та Східної України. Вплив відбувався через як засоби масової інформації, так і культурні заходи. У містах регіону - Сєвєродонецьку, Рубіжному, Лисичанську, Старобільську - гастролювали різні музичні і театральні колективи, проводились виставки, бібліотеки поповнювалися різноманітною літературою українських авторів. I нині тут працюють безліч міжнародних, українських миротворчих і волонтерських організацій. 3 іншого боку, жителі цих міст, зіткнувшись з реальними бойовими діями, відчули ворожість, особисту небезпеку, нестабільність.

Дані соцопитування, проведеного у 2016-2017 рр. Фондом «Демократичні ініціативи імені Ілька Кучеріва» спільно з компанією «Ukrainian Sociology Service» в містах Сєвєродонецьк та Старобільськ Луганської області (Сочиологический опрос, проведенный Фондом Демократические инициативы имени Илька Кучерива. 2016 г., 2017 г.), свідчать про те, що найпоширенішим страхом серед місцевого населення цих міст $є$ ймовірність повернення бойових дій. Так, у Сєвєродонецьку такого розвитку подій бояться 79\%, Старобільську - 77\%. Крім цього, серед першої трійки побоювань жителів Сєвєродонецька - повернення в місто людей «ЛНР» (36\%) і можлива невиплата пенсій і зарплат (34\%). У Старобільську ж соціально-економічні побоювання щодо невиплати пенсій і зарплат поширені серед жителів міста - 58\% містян.

У тому, що між Україною і Російською Федерацією триває війна, переконані $52 \%$ населення Сєвєродонецька, водночас заперечують це лише $2 \%$, але не можуть чітко сформулювати відповідь $46 \%$. У Старобільську велика частина місцевих жителів (49\%) також уважає те, що відбувається між двома країнами, війною. На противагу їм 19\% містян війни між Україною і Росією не помічають, і ще 32\% не визначилися зі своєю позицією.

Практичну роль Росії в конфлікті на Сході України жителі Сєвєродонецька і Старобільська сприймають ідентично, 64\% і 65\% відповідно. Вони вважають, що ця роль полягає передусім у постачанні збройним формуванням «ДНР» $\mathrm{i}$ «ЛНР» зброї, участі збройних сил самої Росії в бойових діях на стороні «ЛНР» і «ДНР» (53\% жителів Сєвєродонецька і 62\% жителів Старобільська. Усі процентні частки прораховані стосовно тих, хто вважає РФ стороною конфлікту на Донбасі).

Таким чином, події військового конфлікту значно скорегували ідентичність мешканців Південного Сходу України.

Згідно з опитуванням Центру ім. Разумкова (Социологические исследования. Опрос в рамках проекта «Реинтеграчия Донбасса в Украину через коммуникащию». г. Северодонецк, г. Старобельск, март-апрель 
2015 г.), 60\% українців уважають, що для побудови держави (і політичної нації) необхідно загальне або подібне бачення майбутнього; при цьому наявність спільного минулого чи спільності погляду на нього і спільності його оцінок не є обов'язковими, обов'язкова лише здатність поважати іншу точку зору на історію. Тобто формування політичної культури та культурної ідентичності нації потребують дотримання верховенства єдиної етичної норми.

Висновки. Таким чином, аналіз даних соціологічних опитувань засвідчив, що культурна самоідентифікація жителів української частини Луганської області зазнала значних змін за період з 2014 р. і понині: ототожнення себе з російською культурою змінилося проукраїнською орієнтацією. Це, по-перше, характеризує явище культурної ідентичності як динамічне утворення, по-друге, дозволяє сформулювати висновок, що системне виховання політичної культури населення в сукупності 3 роботою на культурно-освітньому і дозвіллєвому напрямах впливає на культурну самоідентифікацію людей, аж до кардинальної її зміни.

Перспективи подальших досліджень. Можливі подальші напрями дослідження: вивчення впливу процесів маргіналізації, глобалізації, глокалізації, національного і культурного фундаменталізму й екстремізму на культурну ідентичність жителів України загалом і східних областей України зокрема. Крім того, актуальним є питання узгодження роботи з формування і розвитку ідентичності громадян України в контексті інтеграції до Європи, яка сама зараз переживає не кращі часи і перебуває на етапі власної трансформації.

\section{Список посилань}

Бусол, К. І. та Коваль, Д. О. (2014). Захист культурних цінностей під час збройного конфлікту на Сході України. Українська Революиія гідності, агресія РФ і міжнародне право (с. 815-822). А. В. Задорожній (Ред.). Київ: K.I.C.

Верба, С. та Алманд, Г. Концепиия политической культуры. Взято из http:// politics.ellib.org.ua/pages-3253.html

Російсько-українська війна в культурі. Узято з https:/uk.wikipedia.org/wiki/

Социологические исследования. Опрос в рамках проекта «Реинтеграџия Донбасса в Украину через коммуникаиию». г. Северодонеик, г. Старобельск, март-апрель 2015 г. Взято из novosti.dn.ua/../231210-52zhyteley-severodonecka-schytayut-chto-mezhdu-uk

Социологический опрос, проведенный Фондом Демократические иничиативы имени Илька Кучерива. 2016 г., 2017 г. Взято из https://antikor.com. uasevdon.net/tags/соцопрос/

Социологический опрос, проведенный центром Разумкова 18-23 ноября 2016 г. Взято из https://strana.ua/.../45640-ukrain

Спеизасідання Наџкомісії України з ЮНЕСКО: Наџіональна комісія України у справах ЮНЕСКО визначила перелік першочергових заходів із за- 
хисту культурних та освітніх потреб постраждалих внаслідок російської агресії на сході України та тимчасової окупаиії Криму. 9.07.2018 (2018). http://icr.kiev.ua/ukr/9_07_2018_Speczasidannja_Nackomisiyi_ Ukrayini_Z_YUNESKO

Титова, О. М. (2016). Культурна спадщина Криму та Донбасу: сучасний стан, можливості збереження. Праиі Центру пам'яткознавства, 30, 5-24.

Эриксон, Э. Кризис идентичности. Взято из https://www.psychologos.ru/articles/ view/krizis-identichnosti

\section{References}

Busol, K. I., Koval, D. O. (2014). Protection of Cultural Values in the Armed Conflict in the East of Ukraine. Ukrainian Revolution of Dignity, Russian aggression and international law (pp. 815-822). A. V. Zadorozhniy (Ed.). Kyiv: K.I.S. [In Ukrainian].

Verba, S., and Almand, G. The concept of political culture. Retrieved from http:// politics.ellib.org.ua/pages-3253.html. [In Russian].

Russian-Ukrainian war in culture. Retrived from https:/uk.wikipedia.org/wiki/. [In Ukrainian].

Sociological research. The survey within the framework of the project "Reintegration of Donbass into Ukraine through Communication". Severodonetsk, Starobelsk, March-April 2015. Retrieved from novosti.dn.ua/.../231210-52zhyteley-severodonecka-schytayut-chto-mezhdu-uk. [In Russian].

A sociological survey conducted by the Ilk Kucheriv Foundation for Democratic Initiatives. 2016, 2017. Retrieved from https://antikor.com.uasevdon.net/ tags/ questioning. [In Russian].

A sociological survey conducted by the Razumkov Center on November 18-23, 2016. Retrieved from https://strana.ua/.../45640-ukrain. [In Russian].

Special meeting of the National Commission of Ukraine with UNESCO: The National Commission of Ukraine for UNESCO defines a list of priority measures for the protection of the cultural and educational needs of the victims as a result of Russian aggression in eastern Ukraine and the temporary occupation of Crimea. July 9, 2018 (2018). Retrieved from http://www.youtube.com/ watch. [In Ukrainian].

Titova, O. M. (2016). Cultural heritage of the Crimea and Donbass: the present state, possibilities of preservation. Proceedings of the Center for the Study of Memory, 30, pp. 5-24. [In Ukrainian].

Erickson, E. Crisis of Identity. Retrieved from https://www.psychologos.ru/articles/ view/krizis-identichnosti. [In Russian].

Надійшла до редколегії 15.08.2018 р. 